\title{
In vitro regeneration of fourwing saltbush [Atriplex canescens (Pursh) Nutt.]
}

\author{
B. MEI, E.G. NO, E.L. MCWILLIAMS, J.H. GOULD, AND R.J. NEWTON
}

Authors are graduate student, graduate student, professor, research scientist, and professor, respectively in the Departments of Forest Science and Horticultural Sciences, The Texas Agricultural Experiment Station, Texas AdM University System, College Station, Tex. 77843.

Abstract

A successful, in vitro regeneration system for fourwing saltbush [Atriplex canescens (Pursh) Nutt.] has potential use for mass propagation and genetic engineering of this important range species. This system could be used as a vehicle for gene transfer and for genetic modification of forage quality, stress tolerance, and biomass. The objectives were to develop an in vitro system for shoot production from both leaf discs and axillary buds, and induce root production. Shoot organogenesis (265 shoots) from leaf disc explants was accomplished at rates of 12.3 shoots/disc or 1.7 shoots $/ \mathrm{mm}^{2}$ of leaf disc explants. Root organogenesis was induced in $63 \%$ (168) of the shoots, using indolebutyric acid (IBA, $0.5 \mathrm{mg} \mathrm{liter}^{-1}$ ) and gibberellic acid (GA3, $0.1 \mathrm{mg}^{-1}$ liter) in a Murashige and Skoog (MS) medium. Roots were also induced on shoots placed in soil. Survival of both shoots and plantlets transferred to soil was $65 \%$. Plantlets transferred to a hydroponic solution were twice the height of plantlets grown in soil. For axillary bud multiplication, the number of shoots generated ranged from 0.7 to 9.1 per explant. Roots were induced on $63 \%$ of the shoots, and $58 \%$ survived transfer to soil. The successful production of plantlets using both leaf-disc and axillary-bud methods demonstrates that this important range species can be mass propagated in vitro.

Key Words: tissue culture, organogenesis, leaf disc, axillary bud

Atriplex (saltbush) species are a valuable component of rangelands and are used for forage (Ueckert et al. 1988, Barrow 1989, Rehman et al. 1991), regeneration of disturbed sites (Plummer 1970, Aldon 1978, 1984; Booth 1985), and energy production (Van Epps et al. 1982, Goodin 1984, Newton and Goodin 1985). Progress has been made in the asexual propagation of Atriplex species by cuttings (Weisner and Johnson 1977, Richardson et al. 1979, McArthur et al. 1984) and adventitious shoot production via tissue culture (Wochok and Sluis 1980, Barrow 1989, Wurtele 1989, Tripathy and Goodin 1990). Although Barrow (1989) alluded to root production from shoots, data were not provided. Therefore, root initiation data from in vitro-produced shoots coupled with plantlet production has not been reported. In addition,

This research was supported by the Texas Agricultural Experiment Station, The Temple-Inland Foundation of Diboll, Tex., and the USFS, Coop. Agmt. 28-C8-485. Appreciation is extended to Ms. E. McGee for preparation of this manuscript. Seed were provided by E.F. Aldon, USDA, Forest Service, Rocky Mountain Forest and Range Experiment Station, Albuquerque, N.M.

Manuscript accepted 24 Aug. 1996.

\section{Resúmen}

Se estableció un sistema eficiente para la regeneración in vitro de atriplex [Atriplex canescens (Pursh) Nutt.] con uso potencial en la propagación masiva e ingeniería genética de esta importante especie forrajera. Este sistema puede ser usado como vehículo en la transferencia de genes y para la modificación genética de la calidad de forraje, tolerancia a estres y biomasa. Los objetivos fueron desarrollar un sistema in vitro para la producción de brotes a partir de discos de hoja y yemas axilares, así como la inducción de raíces en los brotes. La organogénesis de brotes se logró ( 265 brotes) a partir de discos de hoja en un rango de 12.3 brotes por disco o 1.7 brotes $/ \mathrm{mm}^{2}$. Se logró un $63 \%$ de enraizamiento de los brotes (168) usando ácido indolbutírico (AIB, $0.5 \mathrm{mg} \mathrm{l}^{-1}$ ) y acido giberélico $\left(\mathrm{GA}_{3}, 0.1 \mathrm{mg} \mathrm{l}^{-1}\right.$ ) en medio de cultivo Murashige y Skoog (MS). Igualmente se indujo enraizamiento de brotes que fueron directamente transplantados a suelo. El porcentaje de sobrevivencia de las plantas producidas in vitro así como de aquellas transplantadas a suelo fué del $65 \%$; sin embargo, después de ser transplantadas a un sistema hidropónico, las plantas producidas in vitro alcanzaron el doble de altura. Para la multiplicación de yemas axilares, el número de brotes regenerados varió de 0.7 a 9.1 por explante. Se logró un $63 \%$ de enraizamiento de los brotes, y $58 \%$ sobrevivieron el transplante al suelo. El éxito en la producción de plantas usando ambos métodos: disco de hoja y yemas axilares, demuestra que esta importante especie forrajera puede ser propagada in vitro.

regeneration by axillary bud multiplication has not been reported for Atriplex.

With the in vitro technique of tissue culture, shoots can either be produced from leaves or from axillary buds. To produce adventitious shoots from leaves, small discs are cut out of the leaf, surface sterilized, and then placed on a solid nutrient medium where they are subjected to a hormone treatment which differentiates the disc tissue first into a callus and with subsequent hormone treatment the callus produces shoots. The shoots are then subjected to an additional hormone treatment to produce roots. The rooted shoot is then referred to as a "plantlet." Shoots can also result from buds located within the axillary angle between the leaf petiole and the stem. When the bud is induced to elongate with a hormone treatment, a small branch with several shoots is produced. The shoots are excised and placed on a solid medium with hormones to induce root formation. Again when roots are formed, the rooted shoot becomes a plantlet. 
As indicated by Wochock and Sluis (1980), a successful regeneration system for Atriplex canescens using tissue culture has potential use in the genetic engineering of this very important rangeland species. Recently, new biotechnologies have been developed to isolate drought-induced genes (Newton et al. 1991, Adair et al. 1992, Funkhouser et al. 1993, Cairney et al. 1995, Chen et al. 1995) and several ozone-induced genes (No 1994) from $A$. canescens. These have a possible use for gene transfer and genetic modification of saltbush for improved resistance to environmental stresses. However, application of gene transfer technology requires an appropriate tissue culture system. Its use in gene transfer would allow researchers to better understand functions of stress-induced genes in $A$, canescens, and provide a rapid means for improving its stress tolerance, biomass production and forage quality. The objectives of this study were to: (1) develop an in vitro system for shoot production from leaf tissue and subsequent root production, and (2) develop a shoot production system from axillary buds.

\section{Materials and Methods}

\section{Plant Material and Media}

Atriplex canescens cv. "Rincon" (McArthur et al. 1984) seedlings were grown in pots and maintained in the greenhouse. Leaves and stem sections of those seedlings were used as explants. To prevent browning of tissues, half-strength Murashige and Skoog (1962) medium (MS) plus sucrose $30 \mathrm{~g} \mathrm{liter}^{-1}$ and Gelrite $4 \mathrm{~g}$ liter $^{-1}$ (gellan gum, Merck \& Co.) were used as the basal medium for shoot initiation. For rooting, the basal medium was full-strength MS medium with sucrose $30 \mathrm{~g} \mathrm{liter}^{-1}$ and Gelrite $4 \mathrm{~g}$ liter ${ }^{1}$.

\section{Organogenesis from Leaf Discs}

Young leaves, 5 nodes or less from the seedling apex, were soaked with $100 \%$ commercial bleach for $20 \mathrm{~min}$, rinsed with sterilized water 6 times (all the sterilization procedures mentioned in other protocols follow the same method), then aseptically cut into small discs and cultured on the appropriate media protocols. Four leaf discs, $3 \mathrm{~mm}$ in diameter, were placed in a petri dish; 8 discs were used for each protocol. Several protocols modified from Barrow (1989) and Tripathy and Goodin (1990) were tried. In contrast to the shoot initiation procedures of Tripathy and Goodin (1990), we used: half-strength MS media, a lower concentration of 2,4-D, and a different nitrogen source. Whereas Barrow (1989) used a modified B5 media amended with picloram and auxin to induce shoots, we used MS media amended with auxin, but not $\mathrm{GA}_{3}$. Our 2 successful protocols are shown in Table 1. The means $\pm S$. E. for each protocol were compared with the t-test at a 0.05 level of significance (Ott, 1988).

Two rooting experiments were conducted. First, 2 different rooting protocols were compared (Protocols 1 and 2, Table 2). Thirty shoots were used in both the IBA-GA 3 and the IAA-BA$\mathrm{GA}_{3}$ protocols, respectively. Second, the optimal rooting media composition was determined by comparing rooting performance as affected by various concentrations of $\mathrm{GA}_{3}$ in a basal MS media with IBA after 30 days (Protocol 3, Table 2). Arc-sine transformations of the rooting percentages for the three $\mathrm{GA}_{3}$ treatments were compared using the comparison test for 2 binomial proportions (Ott 1988).
Table 1. Protocols for shoot organogenesis from leaf discs

\begin{tabular}{|c|c|c|c|}
\hline Protocol & Step & Time & Media Composition \\
\hline & & (days) & \\
\hline \multirow[t]{7}{*}{1} & Callus induction & 30 & $\begin{array}{l}\text { 1/2 MS; kinetin (KT), } 1 \mathrm{mg} \\
\mathrm{l}^{-1} ; 2,4-\mathrm{D}, 0.2 \mathrm{mg} \mathrm{l}^{-1}\end{array}$ \\
\hline & Shoot induction & 30 & $1 / 2 \mathrm{MS} ; \mathrm{KT}, 0.2 \mathrm{mg} \mathrm{l}^{-1}$ \\
\hline & Shoot elongation & 30 & $1 / 2 \mathrm{MS} ; \mathrm{KT}, 0.1 \mathrm{mg} \mathrm{l}^{-1}$ \\
\hline & Proliferation & 15 & $\begin{array}{l}1 / 2 \mathrm{MS} ; \mathrm{BA}, 0.5 \mathrm{mg} \mathrm{l}^{-1} \text {; } \\
\text { gibberellic acid }\left(\mathrm{GA}_{3}\right) \text {, } \\
0.1 \mathrm{mg} \mathrm{l}^{-1}\end{array}$ \\
\hline & Separation of Shoots & & \\
\hline & $\begin{array}{l}\text { Elongation \& } \\
\text { Subculture }\end{array}$ & 15 each & $\begin{array}{l}1 / 2 \mathrm{MS} \text {; thymine (B1), } 1 \mathrm{mg} \\
\mathrm{I}^{-1} ; \mathrm{BA}, 0.01 \mathrm{mg} \mathrm{l}^{-1} ; \\
\text { and } \mathrm{NH}_{4} \mathrm{Cl}, 450 \mathrm{mg} \mathrm{l}^{-1}\end{array}$ \\
\hline & Root Initiation & & See Table 2 \\
\hline \multirow[t]{7}{*}{2} & Callus induction & 30 & $\begin{array}{l}\text { 1/2 MS; IAA, } 0.1 \mathrm{mg} \mathrm{l}^{-1} ; \\
\text { benzy'ladenine (BA), } \\
0.5 \mathrm{mg} \mathrm{l}^{-1} ; \mathrm{NH}_{4} \mathrm{Cl}, 450 \mathrm{mg} \mathrm{l}^{-1}\end{array}$ \\
\hline & Shoot Induction \& & 60 & $\begin{array}{l}\text { 1/2 MS; } 2,4-\mathrm{D}, 0.01 \mathrm{mg} \mathrm{l}^{-1} \\
\text { KT. } 0.5 \mathrm{mg} \mathrm{l}^{-1}\end{array}$ \\
\hline & Elongation & & $\mathrm{NH}_{4} \mathrm{Cl} 450 \mathrm{mg} \mathrm{l}^{-1}$ \\
\hline & Proliferation & 15 & Same as Protocol 1 above \\
\hline & Separation of Shoots & & \\
\hline & Elongation & 15 & Same as Protocol 1 above \\
\hline & Root Initiation & & See Table 2 \\
\hline
\end{tabular}

\section{Organogenesis from Axillary Buds}

Young shoots from greenhouse-derived shrubs containing dormant axillary buds, were surface sterilized, cut into one-bud segments, and placed on 4 different media protocols (Table 3). Each protocol was divided into 2 stages: Stage I for breaking dormancy of the axillary buds and Stage II to enhance shoot extension. For each protocol, 8 stem-segment explants were used. The means \pm S. E. of regenerated shoots per axillary bud for the 4 protocols were compared using analysis of variance (Ott, 1988). After Stage II of organogenesis, the elongated shoots were transferred to the rooting medium (MS; IBA, $0.5 \mathrm{mg} \mathrm{liter}^{-1}$ and $\mathrm{GA}_{3}, 1.0 \mathrm{mg}$ liter $^{-1}$ ) for a period of 30 days.

\section{Transferring Shoots and Plantlets to a Soil Medium}

Shoots without roots and the rooted plantlets were then transferred to a soil medium [perlite, vermiculite and peat moss (2:2:1)]. Three days prior to transfer, test-tube caps were taken off plantlets and shoots, and they were exposed to air and high intensity artificial light (photon flux density, $240 \mu \mathrm{mol} \mathrm{m}{ }^{2}$ ) to harden-off. Before transfer, the rooting rate was recorded. The test-tubes were then soaked in distilled water at room temperature for $20 \mathrm{~min}$ to loosen the attachment of plantlets to the gelrite. Plantlets and shoots were taken out of test-tubes and planted in soil. Fungicides $\left(0.59 \mathrm{ml} \mathrm{gal}^{-1}\right.$ of Subdue, $1.6 \mathrm{~g} \mathrm{gal}^{-1}$ of Benalate) were sprayed on plants after planting. The containers were covered with a piece of thin plastic film and placed into a growth chamber with a relative humidity of $85 \%$, a temperature cycle of $25^{\circ} \mathrm{C}$ day $/ 22^{\circ} \mathrm{C}$ night, and a photoperiod of 16 hours light $/ 8$ hours dark with a light intensity of $240 \mu \mathrm{mol} \mathrm{m} \mathrm{m}^{-2}$. Three days later, the plastic film was removed. The transplants were irrigated daily and liquid fertilizer was dispensed 15 days after transfer at an interval of once per week. One month after transfer, survival rates were recorded. 
Table 2. Protocols for root organogenesis

\begin{tabular}{|c|c|c|}
\hline Protocol & Time & Media Composition \\
\hline 1 & $\begin{array}{l}\text { (days) } \\
30\end{array}$ & $\begin{array}{l}\text { MS; indolebutyric acid (IBA), } 0.5 \mathrm{mg} \mathrm{l}^{-1} \text {; } \\
\mathrm{GA}_{3}, 0.1 \mathrm{mg} \mathrm{l}^{-1}\end{array}$ \\
\hline 2 & 30 & $\begin{array}{l}\text { 1/2 MS; indoleacetic acid (IAA), } 0.2 \mathrm{mg} \mathrm{l}^{-1} \text {; } \\
\text { BA, } 0.1 \mathrm{mg} \mathrm{l}^{-1} ; \mathrm{GA}_{3}, 0.5 \mathrm{mg} \mathrm{l}^{-1}\end{array}$ \\
\hline 3 & 30 & $\begin{array}{l}\text { MS; indolebutyric acid (IBA), } 0.5 \mathrm{mg} \mathrm{l}^{-1} \text {; } \\
\mathrm{GA}_{3}, 0^{-1}, 0.5 \text { and } 1.0 \mathrm{mg} \mathrm{I}^{-1}\end{array}$ \\
\hline
\end{tabular}

Survival percentages for the $3 \mathrm{GA}_{3}$ treatments (Table 2) were compared using arc-sine transformation and the comparison test for 2 binomial proportions (Ott 1988).

\section{Plantlet Hydroponics}

Plantlets derived from leaf discs were potted in soil and grown in the greenhouse for 1 month. From those that survived the transplanting, about 80 were randomly selected and placed in pots (15 $\mathrm{cm}$ high and $15 \mathrm{~cm}$ in diam. with a volume of 2 liters) containing a nutrient solution (Bethke and Drew 1991). In hydroponics, the top and the sides of the pots were covered with aluminum foil to prevent light penetration and growth of algae. Plantlet size (mean \pm S.D.) was recorded at the start of hydroponics and 1 month later. Plantlet size increase in hydroponics and soil culture was further compared for a period of 1 month. Four round holes, $2 \mathrm{~cm}$ diam., were made in the top of each container. Plantlets with roots, $3 \mathrm{~cm}$ or larger, were wrapped with a piece of foam and each held fast to a hole on the top of the container. Air, driven by an aquatic pump, was introduced into the solution via small plastic tubes ( $3 \mathrm{~mm}$ diam.) capped with an injection needle. The nutrient solution was changed every week. The pots were placed in the same growth chamber with the same physical environment as the soil treatment.

Table 3. Protocols for shoot organogenesis from axillary buds

\begin{tabular}{|c|c|c|c|}
\hline Protocol & $\begin{array}{c}\text { Stage } \\
\text { Number }\end{array}$ & Time & Media Composition \\
\hline \multirow[t]{2}{*}{1} & I & $\begin{array}{l}\text { (days) } \\
30\end{array}$ & $\begin{array}{l}\text { 1/2 MS; 2,4-D, } 0.01 \mathrm{mg} \mathrm{l}^{-1} ; \mathrm{KT} \text {, } \\
0.5 \mathrm{mg} \mathrm{l}^{-1} ; \text { and } \mathrm{NH}_{4} \mathrm{Cl}, 450 \mathrm{mg} \mathrm{l}^{-1}\end{array}$ \\
\hline & II & 30 & MS without hormones \\
\hline \multirow[t]{2}{*}{2} & 1 & 30 & $\begin{array}{l}\text { 1/2 MS; IAA, } 0.1 \mathrm{mg} \mathrm{l}^{-1} ; \mathrm{BA}, 2 \mathrm{mg} \mathrm{l}^{-1} \text {; } \\
\text { and } \mathrm{NH}_{4} \mathrm{Cl}, 450 \mathrm{mg} \mathrm{l}^{-1}\end{array}$ \\
\hline & II & 30 & $\begin{array}{l}\text { 1/2 MS; NAA, } 0.01 \mathrm{mg} \mathrm{l}^{-1} ; \mathrm{BA}, 2 \mathrm{mg} \mathrm{l}^{-1} \text {; } \\
\text { and } \mathrm{NH}_{4} \mathrm{Cl}, 450 \mathrm{mg} \mathrm{l}^{-1}\end{array}$ \\
\hline \multirow[t]{2}{*}{3} & $\mathbf{I}$ & 30 & $\begin{array}{l}\text { 1/2 MS; B1, } 1 \mathrm{mg} \mathrm{l}^{-1} ; \mathrm{BA}, 2 \mathrm{mg} \mathrm{l}^{-1} \text {; } \\
\mathrm{NAA}, 0.01 \mathrm{mg} \mathrm{l}^{-1} ; \mathrm{GA}_{3}, 1 \mathrm{mg} \mathrm{l}^{-1} \text {, } \\
\text { and } \mathrm{NH}_{4} \mathrm{Cl}, 450 \mathrm{mg} \mathrm{l}^{-1}\end{array}$ \\
\hline & II & 30 & Same as Stage I. \\
\hline \multirow[t]{2}{*}{4} & I & 30 & $\begin{array}{l}\text { 1/2MS; IAA, } 0.1 \mathrm{mg} \mathrm{l}^{-1} ; \mathrm{BA}, 0.5 \mathrm{mg} \mathrm{l}^{-1} \text {; } \\
\text { and } \mathrm{NH}_{4} \mathrm{Cl} \text {, } \\
450 \mathrm{mg} \mathrm{l}^{-1}\end{array}$ \\
\hline & П & 30 & MS without hormones \\
\hline
\end{tabular}

Table 4. Shoot organogenesis* from leaf explants of Atriplex canescens

\begin{tabular}{lcl}
\hline \hline Protocol & shoots/disc & shoots $/ \mathrm{mm}^{2}$ \\
\hline 1 & $8.6 \pm 1.2^{\mathrm{b}}$ & $1.2 \pm 0.2^{\mathrm{b}}$ \\
2 & $12.3 \pm 1.7^{\mathrm{a}}$ & $1.7 \pm 0.2^{\mathrm{s}}$ \\
\hline
\end{tabular}

*Mean number of shoots \pm S. E. per leaf disc or $\mathrm{mm}^{2}$ of leaf surface

**See Table 2 for protocol descriptions

$* * * 8$ leaf discs, $3 \mathrm{~mm}$ diam.; 4 leaf discs per petri dish; 2 petri dishes per protocol - Means \pm S. D. in columns followed by the same letter are not significantly different at the 0.05 level using the $t$-test (Ott 1988)

\section{Results}

\section{Organogenesis from Leaf Dises}

Shoot organogenesis from leaf discs using 2 different protocols (Table 1) was achieved (Table 4). With the first protocol, using small leaf discs on a medium containing KT and 2,4-D, a thin layer of loose, white to translucent, callus appeared at the midrib and the edge of the leaf disc after 3 days. Subsequently, the callus extended to lateral veins, and then to the whole surface. Callus was more copious at the midrib and the edge of the leaf disc than the other parts. After approximately 1 month's culture and subsequent transfers to shoot induction media, half of the green callus underwent a slow process of change in which its color turned deeper and its texture turned solid (Fig. 1A). On the third medium and while the dominant white callus turned brown and died, the localized, deep green callus turned into a firm and tumor-like structure, from which small shoot clumps eventually differentiated (Fig. 1B). Using this protocol, organogenesis occurred on about $5 \%$ of the leaf disc surface after 3 months' culture. More than 8 shoots per leaf disc resulted (Table 4).

With the second protocol (Table 1), both white and light-green calli were induced from leaf discs cultured on medium containing IAA, BA, and $\mathrm{NH}_{4} \mathrm{Cl}$. Both white and light-green calli were induced on the first medium. One month later, the calli were transferred to a shoot-induction media and after more than 2 months, shoot clumps began to appear from grain-like, green calli, which were evenly scattered among the rest of the white or brown calli. After an overall period of 3 months, organogenesis occurred on about $20 \%$ of the leaf surface, resulting in more than 12 shoots per leaf disc (Table 4).

Calli with the attached shoots were transferred to a shoot proliferation medium (Table 1), and shoot bud number increased twofold after a culture period of 15 days. Over 4000 healthy and vigorous shoot clumps (Fig. 1B) were produced by separating larger clumps into several small ones and subculturing them onto fresh proliferation medium every 15 days. When shoots were separated and transferred to the shoot elongation medium, most of them grew to approximately $1 \mathrm{~cm}$ after 15 days of culture (Fig. 1C).

Of 2 different protocols tested (Table 2), the best root induction from shoots was accomplished with the medium containing IBA. Sixteen of 30 shoots rooted when treated with IBA, and only 7 of 30 rooted in the presence of IAA. It was also observed that those shoots whose roots were induced using IBA exhibited a more vigonous growth than those induced with IAA (data not shown). Therefore in the second experiment where the effects of $\mathrm{GA}_{3}$ on rooting were addressed, IBA was the hormone used (Protocol 3, Table 2). The IBA treatment in combination with 3 different $\mathrm{GA}_{3}$ concentrations resulted in more than $60 \%$ of the shoots producing roots and resulting in 168 plantlets (Table 5) as shown in Fig. 1D. 


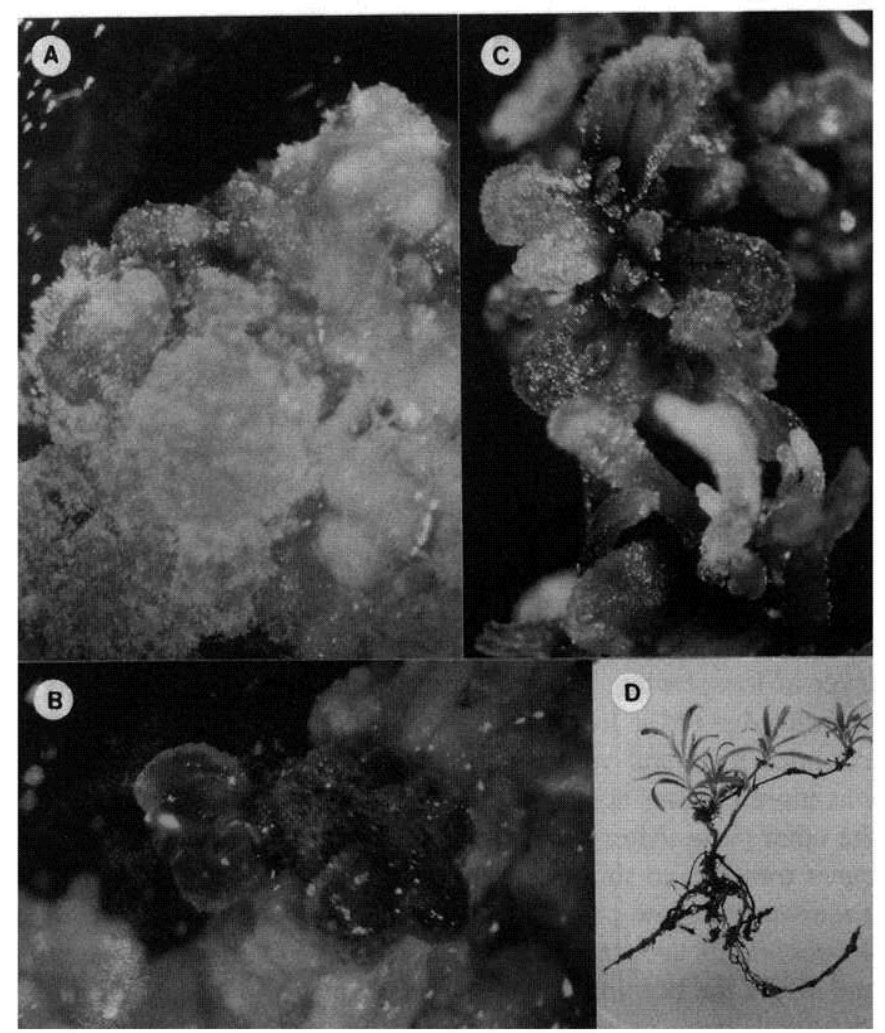

Fig. 1. Organogenesis from leaf disc explants of Atriplex canescens.

(A) A localized green organogenic callus obtained from leaf explants from one-year old greenhouse grown seedlings, and undergoing solidification on 1/2 MS medium plus KT for one month ( $\left.0.2 \mathrm{mg} \mathrm{liter}^{-1}\right)(10 \mathrm{X})$. (B) Shoots derived from organogenic callus on the third medium: $1 / 2 \mathrm{MS}$ medium plus KT $\left(0.1 \mathrm{mg}\right.$ liter $\left.{ }^{-1}\right)$ for one month (10X). (C) A single shoot derived from organogenic callus on 1/2 MS as basal medium plus B1 $\left(1 \mathrm{mg}\right.$ liter $\left.{ }^{-1}\right)$, BA $(0.01$ mg liter') for one month (10X). (D) Plant derived via organogenesis $(0.5 \mathrm{X})$.

IBA in combination with the lower $\mathrm{GA}_{3}$ treatment $\left(0.1 \mathrm{mg} \mathrm{liter}{ }^{-1}\right)$, induced $85 \%$ of the shoots to root (Table 5). Those shoots which had not yet produced roots after 1 month on induction medium were transferred to soil along with the rooted shoots. The rooting percentage ranged from 49 to $85 \%$ with more than $60 \%$ of the combined shoots plus plantlets surviving after transfer to soil (Table 5), indicating that several shoots eventually produced roots when introduced into the soil. This was estimated to be about $40 \%$ of those nonrooted shoots that had been induced in the presence of 0.5 and $1.0 \mathrm{mg} \mathrm{liter}^{-1} \mathrm{GA}_{3}$. Those induced with lower $\mathrm{GA}_{3}\left(0.1 \mathrm{mg} \mathrm{liter}^{-1}\right)$ did not survive when transferred to soil, presumably because they did not form roots.

\section{Organogenesis from Axillary Buds}

Using 4 different protocols consisting of 2 stages each (Table 3), shoot multiplication from axillary buds was initiated by first breaking their dormancy and then inducing shoots with a cytokinin (Fig. 2A). In some cases the initiated shoots died; however, a second round of shoots grew out from the axillary bud and survived. A single axillary bud could be multiplied into a small compact clump with several shoots (Fig. 2B). The mean number of regenerated shoots per explant ranged from 0.74 to 9.11 (Table 6). During Stage II, shoots were cultured on media with or without hormones (Table 3) and allowed to elongate. One hundred and 12 of 178 shoots (63\%) derived from axillary bud multiplication were rooted after 1 month's subculture in rooting medium. One hundred rooted plantlets derived from axillary-bud multiplication were transferred to soil and after one month, 58 plantlets survived (58\%). A total of 4 months was required from initiation of axillary buds to the establishment of plantlets in soil.

\section{Hydroponics of Plantlets}

Eighty-eight plantlets with an average height of $4.8 \pm 1.3 \mathrm{~cm}$ and placed in hydroponic culture for 1 month, increased to a mean height of $23.5 \pm 6.3 \mathrm{~cm}$. However, it was still not clear whether the rapid growth of these plants was due to the favorable physical conditions of the growth chamber or the combined effect of the growth chamber plus the hydroponic medium. Therefore, growth of the plantlets in hydroponic and soil culture was compared. Plantlets in hydroponics increased in size from $4.0 \mathrm{~cm}$ to $20.4 \mathrm{~cm}$ in 4 weeks, while plantlets in soil culture increased from 4.6 to $11.0 \mathrm{~cm}$ in the same period (Fig. 3). In addition, plantlets transferred to hydroponic culture resumed their regular growth sooner ( 1 week) than did the plantlets in soil culture ( 2 weeks) (Fig. 3), and hydroponically-grown plantlets had more welldeveloped root systems (data not shown).

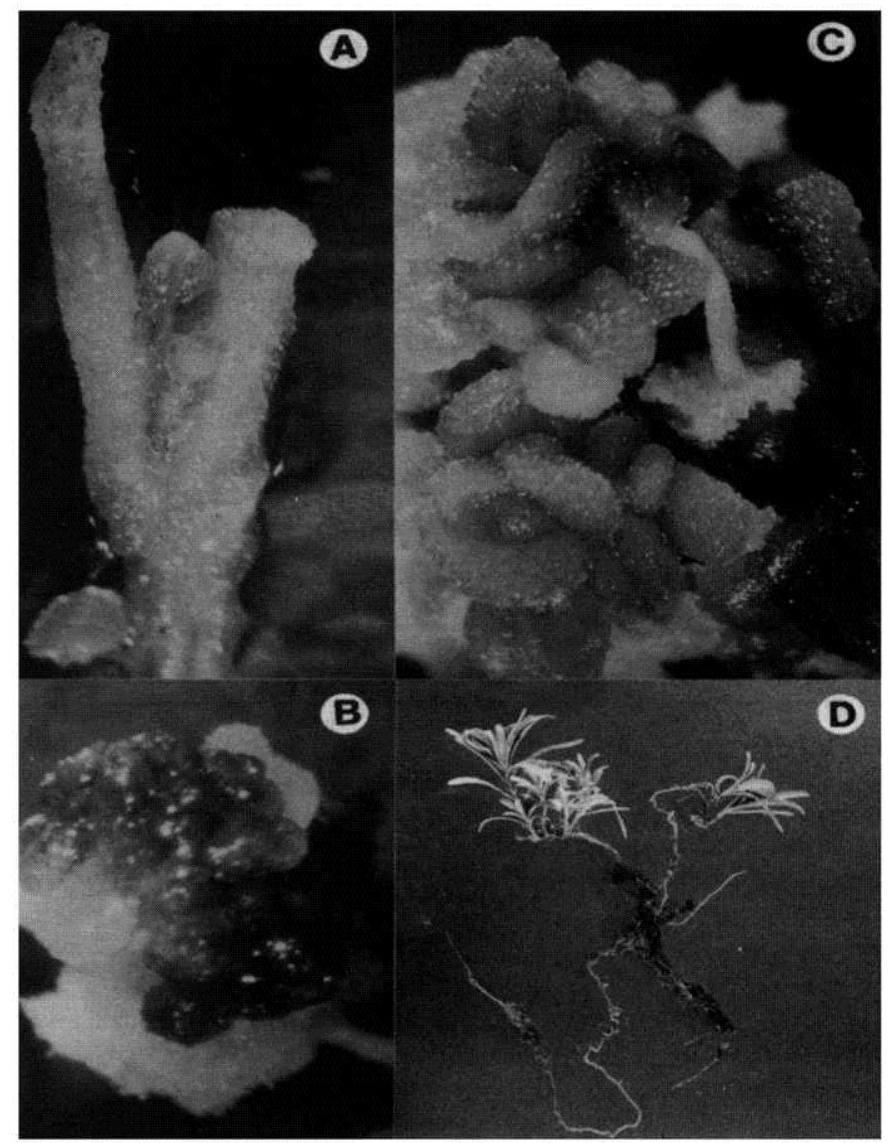

Fig. 2. Initiation and elongation of shoots derived from axillary-bud stem explants of Atriplex canescens.

(A) A single shoot derived from a single axillary bud on 1/2 MS plus IAA (0.1 mg 1iter $\left.{ }^{-1}\right)$, BA (0.5 mg liter $\left.{ }^{-1}\right)$ and $\mathrm{NH}_{4} \mathrm{Cl}(450 \mathrm{mg}$ liter $\left.^{-1}\right)$ for one month $(10 \mathrm{X})$. (B) Proliferation of shoots from a single axillary bud on the same medium as in Fig. $A$ for one month (10X). (C) Elongation of shoots derived from axillary buds on MS basal medium without hormones added for one month (10X). (D) Plant derived from axillary bud $(0.5 \mathrm{X})$. 
Table 5. Effects of IBA and $\mathrm{GA}_{3}$ on root induction from shoots of Atriplex canescens derived from leaf disc explants and survival after transfer to soil.

\begin{tabular}{|c|c|c|c|c|c|c|}
\hline Protocol* & Number of Shoots & $\begin{array}{l}\text { Rooting } \\
\text { Number }\end{array}$ & Rooting & $\begin{array}{c}\text { Total } \\
\text { Number of Shoots } \\
\text { and Plantlets Planted** }\end{array}$ & $\begin{array}{l}\text { Total } \\
\text { Survival } \\
\text { Number*** }\end{array}$ & $\begin{array}{c}\text { Total } \\
\text { Survival }\end{array}$ \\
\hline 1 & 78 & 66 & $85^{n}$ & 78 & 30 & $38^{\mathrm{b}}$ \\
\hline 2 & 84 & 41 & $49^{c}$ & 84 & 60 & $71^{2}$ \\
\hline 3 & 103 & 61 & $59^{b}$ & 103 & $\underline{81}$ & $\underline{79}^{\mathrm{a}}$ \\
\hline
\end{tabular}

* See Table 2 for protocol descriptions

** Shoots grown in vitro with no visible roots as well as rooted shoots were planted in soil

***Included shoots that produced roots after transfer to soil

a.b Percentages in columns followed by the same letter are not significantly different at the 0.05 level after are sine

transformation and using the comparison test for two binomical proportions (Ott 1988)

\section{Discussion}

This is the first data report of root organogenesis from adventitious shoots of Atriplex canescens and resulting in intact plantlets. Shoot induction took at least 3 months and only 2 out of several different protocols tested were successful. Green callus production, followed by callus solidification appeared to be essential for the differentiation of shoots. Several other variations in the media were tried but they were not successful. Protocol 2 may be more effective than Protocol 1 in terms of the number of shoots induced per unit area of leaf surface perhaps as a result of the higher cytokinin concentration (Table 4), whereas shoot buds

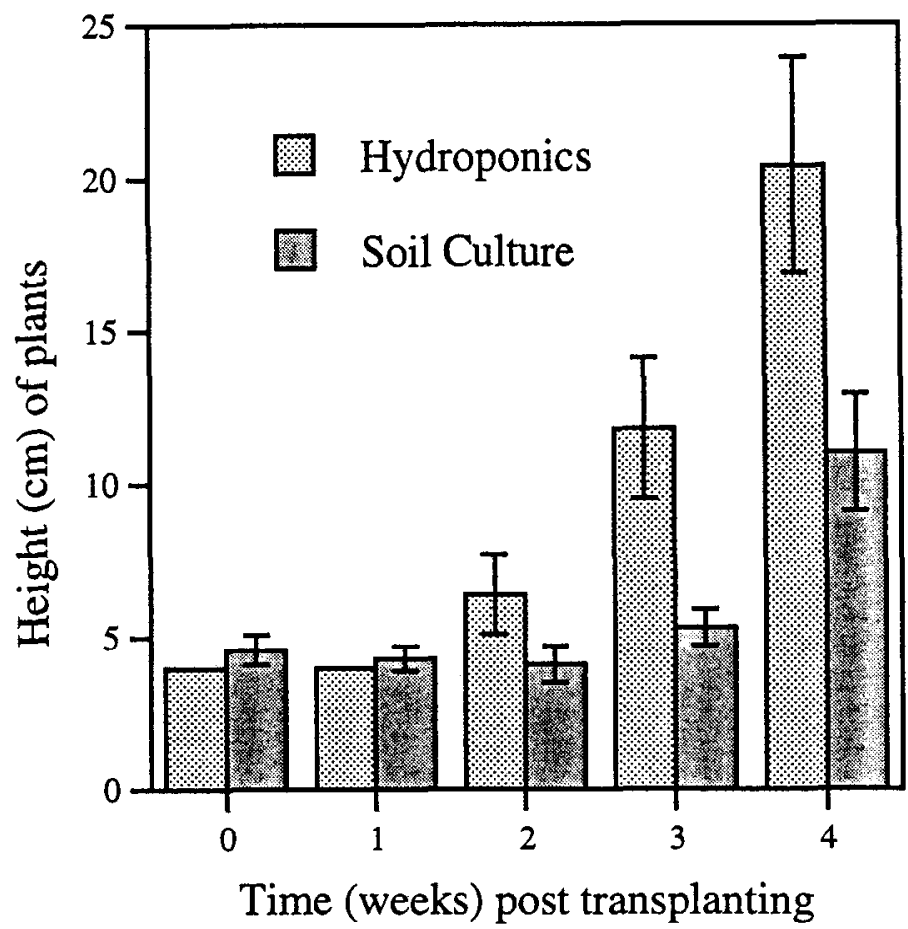

Fig. 3. A growth comparison in hydroponics and soil of plantlets of Atriplex canescens. Eight plantlets per treatment; soil culture with perlite, vermiculite and peatmoss (2:2:1). Potted plantlets were irrigated every other day and fertilized once a week. Bars represent the mean with S.D. induced with Protocol 1 grew faster and more vigorously. Because Tripathy and Goodin (1989) used whole leaves and Barrow (1989) used hypocotyl sections as explant sources for callus initiation and we used leaf discs, comparison of efficiencies of shoot production between our method and theirs is not possible. It appears that all methodologies, regardless of their slight differences, were conducive to shoot production. However, it appears that the specific conditions in which the shoots were produced by Barrow (1989) and Tripathy and Goodin (1989) may have subsequently contributed to the recalcitrance of these shoots to root, or the rooting response may be genotype-specific. Another explanation for our success in rooting could be the lower 2,4-D concentration or the nitrogen source $\left(\mathrm{NH}_{4} \mathrm{Cl}\right)$ that we used in shoot establishment. Nevertheless, as many as $85 \%$ of the shoots produced using our methodology rooted when placed on the appropriate induction medium.

Previous workers have reported shoot induction from Atriplex canescens explants, but root establishment data from these shoots were not provided. We have shown that rooting can be established, on average, on more than $60 \%$ of the adventitious shoots using IBA in combination with $\mathrm{GA}_{3}$. Hence, plantlet production via leaf disc organogenesis is possible with fourwing saltbush with as much as $80 \%$ of them surviving transfer to soil. This is also the first report of saltbush plantlet production from axillary buds with over $60 \%$ of the elongated shoots subsequently producing roots and resulting in plantlets in which nearly $60 \%$ survived. The time required to produce adventitious shoots from leaf callus

Table 6. Shoot organogenesis and elongation from axillary-bud explants* of Atriplex canescens.

\begin{tabular}{lcc}
\hline Protocol** & $\begin{array}{c}\text { Number Regenerated } \\
\text { Shoots/Axillary Bud }\end{array}$ & $\begin{array}{c}\text { Length of Regenerated } \\
\text { Shoots }\end{array}$ \\
\hline & & $(\mathrm{mm})$ \\
1 & $0.76 \pm 0.17 \mathrm{~b}$ & $0.6-4.0$ \\
3 & $9.11 \pm 3.71 \mathrm{a}$ & $1.8-6.0$ \\
4 & $0.74 \pm 0.84 \mathrm{~b}$ & $3.9-7.7$ \\
\hline
\end{tabular}

*Each stem explant segment contained one axillary bud. For each protocol, 8 stem segment explants were used.

** See Table 3 for protocol descriptions

2.b Means + S.D. followed by the same letter within columns are not significantly different at the 0.05 level using analysis of variance (Ott 1988). 
was longer than that required for axillary-bud shoot production (2 versus 3 months). Another additional benefit of axillary-bud shoot production is that this regeneration process bypasses the callus induction stage needed in adventitious shoot production, thus greatly reducing the initiation of mutations that lead to deviation from the true genotype.

However, both of these techniques could be used for mass propagation of this important range species, particularly with hydroponic culture. Hydroponically-grown plantlets displayed a more vigorous growth and a more developed root system than did soil-grown plantlets. It has the potential to enhance growth, and therefore shorten the holding time before plantlets are incorporated into commercial use.

\section{Conclusions}

Mass micropropagation of Atriplex canescens using both shoot and root organogenesis resulting in the production of intact plantlets has been accomplished. In addition, this is the first report of saltbush plantlet production from axillary buds. Shoots established in the presence of kinetin (callus culture) or cytokinin (axillary bud culture), 2,4-D and $\mathrm{NH}_{4} \mathrm{CL}$, subsequently rooted when induced with IBA and $\mathrm{GA}_{3}$. Hydroponic culture of plantlets was successful. These propagation techniques can be used to mass produce $A$. canescens as well as for gene transfer, using either the leaf-disc (Horsch at al. 1985) or the shoot apex (Gould at al. 1991) method of transformation. A well-established regeneration system plus a successful gene transfer system would allow for improvement of saltbush as a forage, and would contribute to better understanding of the genetic basis of this species in terms of stress resistance and protein production.

\section{Literature Cited}

Adair, L.S., D.L. Andrews, J. Cairney, E.A. Funkhouser, R.J. Newton, and E.F. Aldon. 1992. Characterizing gene responses to drought stress in fourwing saltbush (Atriplex canescens (Pursch) Nutt.). J. Range Manage. 45(5):454-461.

Aldon, E.F. 1978. Reclamation of coal-mined land in the Southwest. J. Soil Water Conserv. 33:75-79.

Aldon, E.F. 1984. Methods of establishing fourwing saltbush (Atriplex canescens (Pursch) Nutt.) on disturbed sites in the southwest. p. 254 258. In: A.R. Tiedmann, E.D. McArthur, H.C. Stutz, R. Stevens, and K.L Johnson (compilers). Proc. Symp. on the Biology of Atriplex and Related Chenopodes. May 2-6, 1983. Provo, Ut., USDA, Forest Serv., Intermtn. Forest and Range Exp. Sta., Ogden, Ut., Gen. Tech. Rep. INT-172.

Barrow, J.R. 1989. Organogenesis and shoot-tip multiplication from tissue cultures of Atriplex species. p. 37-39. In: A. Wallace, E.D. McArthur, and M.R. Haferkamp (compilers). Proc. Symp. on Shrub Ecophysiol. and Biotech., Intermtn. Res. Sta., Ogden, Ut., Gen Tech Rep. INT-256.

Bethke, P.C. and M.C. Drew. 1991. Stomatal and nonstomatal components to inhibition of photosynthesis in leaves of Capsicum annum during progressive exposure to $\mathrm{NaCl}$ salinity. Plant Physiol. 99:219-226.

Booth, D.T. 1985. The role of fourwing saltbush in mined reclamation: a viewpoint. J. Range Manage. 38(6):562-565.

Cairney, J., R.J. Newton, E.A. Funkhouser, and S. Chang. 1995. Nucleotide sequence of a cDNA from Atriplex canescens (Pursch) Nutt. A homolog of a jasmonate-induced protein from barley. Plant Physiol. 108(3):1289.
Chen, J., A.J. Reinisch, L.S. Adair, E.A. Funkhouser, J. Cairney, and R.J. Newton. 1995. Isolation, sequence, and expression analysis of two water-deficit-induced cDNA clones from the halophyte Atriplex canescens (saltbush). Physiol. Plant. 96:401-410.

Funkhouser, E.A., J. Cairney, S. Chang, M.A.D. Dias, and R.J. Newton. 1993. Cellular and molecular responses to water deficit stress in woody plants. p. 347-362. In: M. Pessarakli (ed.). Handbook of Plant and Crop Stress. Marcel Dekker, Inc. N.Y.

Goodin, J.R. 1984. Assessment of the potential of halophytes as energy crops for the electric utility industry. Elect. Power Res. Inst. Palo Alto, Calif. AP-35897.

Gould, J.H., M.E. Devey, O. Hasegawa, E.C. Ulian, G. Peterson, and R.H. Smith. 1991. Transformation of Zea mays L. using Agrobacterium tumefaciens. Plant Physiol. 95:426-434.

Horsch, R.B., Fry, J.E., N.L. Hoffman, D. Eichholtz, S.G. Rogers, and R.T. Fraley. 1985. A simple and general method for transferring genes into plants. Science 227:1229-1231.

McArthur, E.D., S.E. Stranathan, and G.L. Noller. 1984. "Rincon" fourwing saltbush-proven for better forage and reclamation. Rangelands 6(2):62-64.

Murashige, T. and F.A. Skoog. 1962. A revised medium for rapid growth and bioassay with tobacco tissue cultures. Physiol. Plant. 15:473-497.

Newton, R.J. and J.R. Goodin. 1985. Unconventional arid land plants as biomass feedstocks for energy. p. 387-397. In: G.E. Wickens, J.R. Goodin, and D.V. Field (eds.). Plants for Arid Lands. George Allen \& Unwin. England.

Newton R.J., E.A. Funkhouser, F. Fong, and C.G. Tauer. 1991. Molecular and physiological genetics of drought tolerance in forest species. Forest Ecol. Manage. 43:225250.

No, E.-G. 1994. Isolation and characterization of five ozone inducible genes of Atriplex canescens. M.S. Thesis, Plant Physiology, Texas A\&M Univ., College Station, Tex.

Ott, L. 1988. An introduction to statistical methods and data analysis. (3rd ed.). PWS-KENT Publishing Co. Boston, Mass.

Plummer, A.P. 1970. Plants for regeneration of roadcuts and other disturbed or eroded areas. USDA, Forest Serv., Intermtn. Range Improv. Notes. 15: 1-8.

Rehman, A., S. Rafique, and B. Khan. 1991. Fourwing saltbush as a winter forage for sheep in upland Balochistan. ACIAR Proceedings. 42:75-78.

Richardson, S.G., J.R. Barker, K.A. Crofts, and G.A. Van Epps. 1979. Factors affecting rooting of stem cuttings of salt desert shrubs. J. Range Manage. 32(4):280-283.

Tripathy, S. and J.R. Goodin. 1990. Micropropagation of elite biotypes of fourwing saltbush. p. 336-342. In: E.D. McArthur, E.M. Romney, S.D. Smith, and P.T. Tuellen (compilers). Proc. Symp. on Cheatgrass Invasion, Shrub Die-off, and Other Aspects of Shrub Biology and Management. USDA Forest Serv. Intermtn. Res. Sta., Ogden, Ut. Gen. Tech. Rep. INT-276.

Ueckert, D.N., M.W. Wagner, J.L. Peterson, and J.E. Houston. 1988. Performance of sheep grazing fourwing saltbush during winter. $p$. 32-33. In: Sheep and goat, wool, and mohair. Tex. Agr. Exp. Stn. College Station, Tex.

Van Epps, G.A., J.R. Barker, and C.M. McKell. 1982. Energy biomass from large rangeland shrubs of the intermountain United States. J. Range Manage. 35(1):22-25.

Wiesner, L.E. and W.J. Johnson. 1977. Fourwing saltbush (Atriplex canescens) propagation techniques. J. Range Manage. 30(2):154-156.

Wochok, Z.S. and C.J. Sluis. 1980. Gibberellic acid promotes Atriplex shoot multiplication and elongation. Plant Sci. Lett. 17:363-369.

Wurtele, E.S. 1989. Responses of callus cultures, microshoot cultures, and whole plants of the halophyte, Atriplex canescens var. gigantea to exogenous $\mathrm{NaCl}$. p. 40-48. In: A. Wallace, E.D. McArthur, and M.R. Haferkamp (compilers). Proc. Symp. on Shrub Ecophysiology and Biotechnology. USDA, Forest Serv., Intermtn. Res. Sta., Ogden, Ut. Gen. Tech. Rep. INT-256. 